\title{
CaM-kinasell-dependent commitment to microcystin- induced apoptosis is coupled to cell budding, but not to shrinkage or chromatin hypercondensation
}

\author{
C Krakstad ${ }^{1}$, L Herfindal ${ }^{1}$, BT Gjertsen ${ }^{2}$, R Bøe ${ }^{1}$, OK Vintermyr ${ }^{3}$, \\ KE Fladmark ${ }^{1}$ and SO Døskeland ${ }^{\star, 1}$ \\ ${ }^{1}$ Cell Biology Research Group, Section of Anatomy and Cell Biology, \\ Department of Biomedicine, University of Bergen, Jonas Lies vei 91, N-5009 \\ Bergen, Norway \\ 2 Department of Internal Medicine, Haukeland University Hospital, Bergen, \\ Norway \\ ${ }^{3}$ The Gade Institute, Haukeland University Hospital, Bergen, Norway \\ * Corresponding author: SO Døskeland, Cell Biology Research Group, Section \\ of Anatomy and Cell Biology, Department of Biomedicine, University of \\ Bergen, Jonas Lies vei 91, N-5009 Bergen, Norway. Tel: + 4755586376 \\ Fax: + 47 55586360; E-mail: stein.doskeland@biomed.uib.no
}

Received 16.5.05; revised 19.8.05; accepted 31.8.05; published online 25.11.05 Edited by John Cidlowski

\section{Abstract}

The protein phosphatase inhibitor microcystin-LR (MC) induced hepatocyte apoptosis mediated by the calciumcalmodulin-dependent multifunctional protein kinase II (CaMKII). CaMKII antagonists were added at various times after MC to define for how long the cells depended on CaMKII activity to be committed to execute the various parameters of death. Shrinkage and nonpolarized budding were reversible and not coupled to commitment. A critical commitment step was observed $15-20 \mathrm{~min}$ after $\mathrm{MC}(0.5 \mu \mathrm{M})$ addition. After this, CaMKII inhibitors no longer protected against polarized budding, DNA fragmentation, lost protein synthesis capability, and cell disruption. Commitment to chromatin hypercondensation occurred $40 \mathrm{~min}$ after MC addition. In conclusion, irreversible death commitment was coupled to polarized budding, but not to shrinkage or chromatin condensation. Antioxidant prevented chromatin condensation when given after the CaMKII-dependent commitment point, suggesting that CaMKII had mediated the accumulation of a second messenger of reactive oxygen species nature.

Cell Death and Differentiation (2006) 13, 1191-1202.

doi:10.1038/sj.cdd.4401798; published online 25 November 2005

Keywords: protein phosphorylation; morphology; toxins

Abbreviations: CaMKII, calcium-calmodulin-dependent multifunctional protein kinase II; MC, microcystin-LR; PP1, phosphoprotein phosphatase type 1; PP2A, phosphoprotein phosphatase type $2 \mathrm{~A}$; TEM, transmission electron microscopy

\section{Introduction}

The evolutionary conserved major serine/threonine protein phosphatases (PP) 1, 2A, 4, 5, and 7 have an inhibitory site targeted by strikingly diverse toxins from marine dinoflagellates (okadaic acid), terrestrial fungi (calyculin A), cyanobacteria (microcystins, nodularin), soil bacteria (tautomycin), and venomous insects (cantharidin). ${ }^{1,2}$ That so many toxins converge on the same target suggests that PP inhibition is able to seriously perturb eukaryotic cells in general. One way in which this can happen is by PP inhibitors short-circuiting an apoptogenic cell stress pathway induced by ionizing radiation. ${ }^{3}$ We reported early that the PP-inhibiting toxins induced morphological alterations compatible with apoptosis in a number of cell types. ${ }^{4,5}$ It was also found early that okadaic acid and microcystin could alter the cytoskeleton of fibroblasts and hepatocytes without inducing death. ${ }^{6,7}$ It is still not settled whether the hepatotoxicity of microcystin is due to a reversible cytoskeletal derangement ${ }^{6-8}$ inducing liver bleeding and secondary hepatocyte necrosis due to insufficient blood supply, ${ }^{9}$ or primarily due to an apoptotic process.

We have found that the majority of the PP-inhibitor-induced protein phosphorylation events in hepatocytes and apoptosis itself require active calcium-calmodulin-dependent multifunctional protein kinase II (CaMKII). ${ }^{10,11}$ This enzyme is activated by $\mathrm{Ca}^{2+}$ /calmodulin, autophosphorylation, or limited proteoIysis. ${ }^{12,13}$ It has been reported that CaMKII is activated by caspases and can thereby contribute to downstream events in apoptosis. ${ }^{14}$ It has also recently been postulated that CaMKII is activated late in the process of microcystin-induced apoptosis through increase of intracellular $\mathrm{Ca}^{2+}$ secondary to severe mitochondrial damage. ${ }^{15,16}$ This would imply that CaMKII only has a role late in the downstream apoptosis signaling modulating the phenotype of PP-inhibitor-induced death.

The present study was undertaken to know whether CaMKII acted upstream or downstream of the commitment point for cell death. If CaMKII acted upstream, we wanted to define the critical period when the kinase had to be active to irreversibly commit PP-inhibitor-treated hepatocytes to various indices of death, like shrinkage, budding, chromatin hypercondensation, loss of attachment to substratum, loss of protein synthesis capacity, extensive DNA fragmentation, and cell swelling and disruption. This would help clarify the unresolved issue of whether PP inhibitors acted primarily on the cytoskeleton with cell death as a late consequence, or acted to irreversibly commit the cells to death at an early stage.

To resolve these issues, we added cell-penetrating CaMKII inhibitors ${ }^{11}$ to microcystin-treated hepatocytes in various preapoptotic stages and studied the cells for later development of morphological and functional signs of cell death.

We defined a CaMKII-dependent commitment time point for polarized cell budding and plating ability, which preceded the one for chromatin hypercondensation, but coincided with the commitment point for death, as defined by irreversible loss of protein and 
DNA synthesis activity and susceptibility to secondary necrosis with DNA fragmentation and finally cell disruption.

\section{Results}

\section{Microcystin induces not only morphological rearrangements of hepatocytes resembling apoptosis, but also irreversible loss of hepatocyte viability}

The purpose of the present study was to define the time periods when CaMKII activity was required to commit hepatocytes to various indices of apoptosis, but we needed first to know whether the phosphatase inhibitors induced loss of viability and not only induced cytoskeletal rearrangements resembling those found in bona fide apoptosis. ${ }^{7}$

We noted that hepatocytes incubated for $2 \mathrm{~h}$ with a moderate $(0.5 \mu \mathrm{M})$ concentration of microcystin-LR $(\mathrm{MC})$ had a dramatically altered structure, including cytoplasmic and nuclear shrinkage, disappearance of microvilli, budding of the cell surface, and chromatin margination and hypercondensation. The cytoplasmic shrinkage at this late stage of MC treatment was due in part to shedding of organelle-rich apoptotic bodies. This was reflected by a decreased number of mitochondria per cell. The average mitochondrial volume remained stable (Table 1). The cells excluded trypan blue (not shown). To know if increased $\mathrm{Ca}_{\mathrm{i}}^{2+}$ from influx or from intracellular stores could contribute to the MC effect, we suspended the cells in $\mathrm{Ca}^{2+}$-free medium with $2 \mathrm{mM}$ EGTA and $4 \mu \mathrm{M}$ of the intracellular $\mathrm{Ca}^{2+}$-chelator BAPTA ${ }^{17}$ or from $60-500 \mu \mathrm{M}$ of the intracellular $\mathrm{Ca}^{2+}$-chelator Quin2-AM. These chelators did not affect the MC induction of apoptotic indices, the percentage of budded cells being 86 (range $81-91 ; n=4$ ) in control cells treated with $0.5 \mu \mathrm{M} \mathrm{MC}$ for $30 \mathrm{~min}, 84$ (range $80-92 ; n=3$ ) in cells having received $4 \mu \mathrm{M}$ BAPTA 15 min before the addition of $\mathrm{MC}$, and 85 (range 78-93; $n=4$ ) when $500 \mu \mathrm{M}$ Quin2-AM was added. This suggested that no significant increase of intracellular $\mathrm{Ca}^{2+}$ was required. With $40 \mu \mathrm{M}$ of BAPTA, we observed a slight retardation of the $\mathrm{MC}$-induced changes $(70 \%$ budding after $30 \mathrm{~min}$ of MC incubation; range $62-77 ; n=3$ ), but full apoptosis ( $97 \%$ budding; $n=3$ ) was observed after $1 \mathrm{~h}$ of incubation. This suggested that a minimum level of $\mathrm{Ca}^{2+}$ could be required for optimal $\mathrm{MC}$ effect.

We did not note internucleosomal fragmentation of DNA from freshly prepared cells treated for up to $3 \mathrm{~h}$ in suspension culture in Krebs-Ringer medium with any of the phosphatase inhibitors MC, okadaic acid, or calyculin A (Figure 1, left four lanes). When the incubation was continued for another $2 \mathrm{~h}$ in suspension and then for $4 \mathrm{~h}$ in a rich cell medium in collagencoated culture dishes, we observed that cells treated with $2 \mu \mathrm{M} \mathrm{MC}$ failed to attach, showed strong internucleosomal DNA fragmentation (Figure 1, lane 7), lost their ability to exclude trypan blue, underwent progressive cell and mitochondrial swelling, and finally disintegrated (not shown). A substantial percentage (15-25\%) of control cells incubated for similar time in the same media also failed to attach to the substratum, and showed extensive DNA fragmentation (Figure 1, lane 6). The majority of the control cells attached to the substratum, however, and showed little fragmentation (Figure 1, lane 5). We conclude that MC had induced cell death based on extreme chromatin condensation and

Table 1 Ultrastructural features of hepatocytes undergoing MC-induced apoptosis (effect of CaMKII inhibitor)

(A) Control

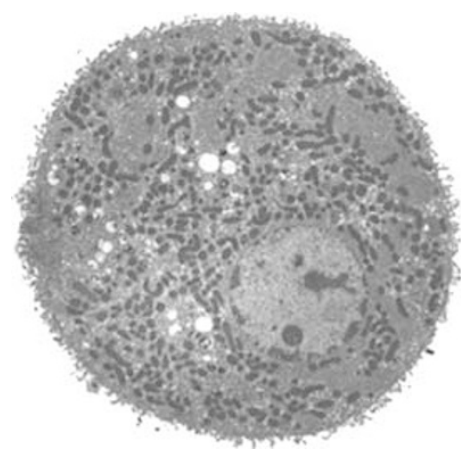

Cell vol. ${ }^{*}\left(\mu \mathrm{m}^{3}\right)$

Nuclear vol. $\left(\mu \mathrm{m}^{3}\right)$

Nucl. vol. (\%)

Mitoch. vol. ${ }^{*}\left(\mu \mathrm{m}^{3}\right)$

Mitoch. vol. $(\%)$

Mitoch. per cell

Glycogen: vol. (\%)
(B) $0.5 \mu \mathrm{M}$ MC-LR

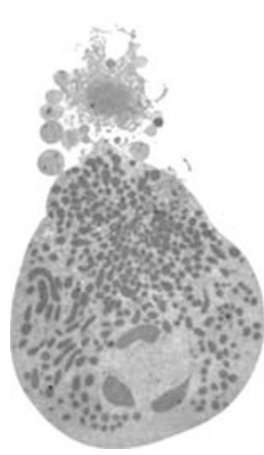

2720
155
8
0.30
16.8
1530

0
(C) $0.5 \mu \mathrm{M}$ MC-LR+5 $\mu \mathrm{M}$ KN62

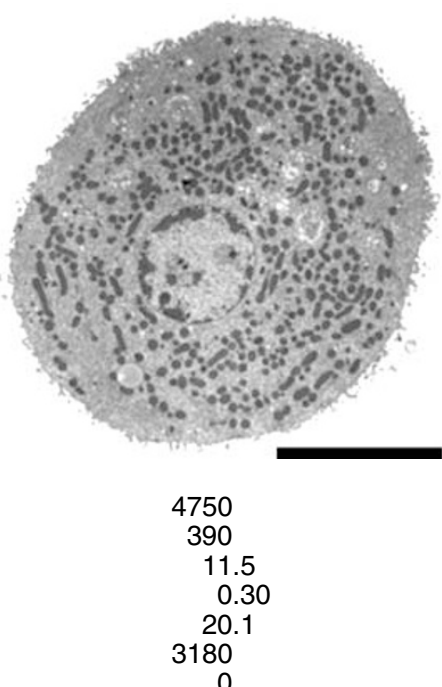

Primary hepatocytes, freshly isolated from rat liver, were incubated for $2 \mathrm{~h}$ prior to fixation, embedding, and electron microscopy, as described in the Materials and Methods section. The table shows micrographs and selected morphometric parameters for (A) control cells, (B) cells treated with $0.5 \mu \mathrm{M}$ MC, and (C) cells treated with $0.5 \mu \mathrm{M} \mathrm{MC}$ in the presence of the CaMKII antagonist KN62. The morphometric data were determined by using transparent test systems superimposed over TEM micrographs as described in the Materials and Methods section. Data marked with an asterisk (i.e. cell volume and mitochondrial number) were derived from the direct measured results (i.e. nuclear volume, mitochondrial volume, and their volume fractions). The bar represents $10 \mu \mathrm{m}$ 


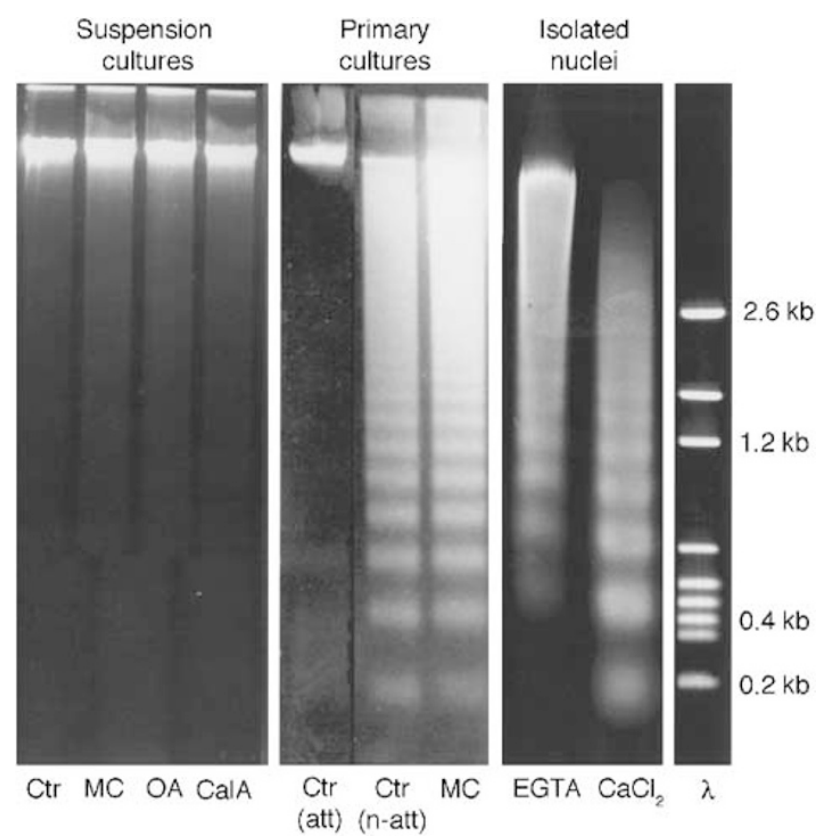

Figure 1 The DNA fragmentation pattern in attached and nonattached phosphatase inhibitor-treated hepatocytes and in isolated hepatocyte nuclei. Rat hepatocyte DNA was subjected to electrophoresis in 1\% agarose. Some cells had been treated in suspension culture for $3 \mathrm{~h}$ without additions (lane 1 ; Ctr), or with the PP inhibitors MC (2 $\mu \mathrm{M}$; lane 2; MC), okadaic acid (0.6 $\mu \mathrm{M}$; lane 3; OA), or calyculinA $(0.1 \mu \mathrm{M}$; lane 4 ; CalA). Note the lack of noticeable DNA fragmentation in any of these cell samples. Other cells were preincubated for $5 \mathrm{~h}$ plated on collagen-coated dishes, left for another $4 \mathrm{~h}$, and the attached and nonattached cells collected for extraction of DNA. The attached cells preincubated without phosphatase inhibitor (lane 5 , Ctr) had mainly apparently intact DNA, whereas nonattached cells had highly fragmented DNA (lane 6, Ctr). Cells preincubated with $2 \mu \mathrm{M}$ MC were all nonattached and had severe DNA fragmentation (lane $7, \mathrm{MC}$ ). Note that DNA from a similar number of cells was loaded in each lane. Nuclei freshly isolated from normal hepatocytes were incubated for $1 \mathrm{~h}$ in $25 \mathrm{mM}$ Hepes buffer, pH 7.0 , with $0.13 \mathrm{M} \mathrm{KCl}, 1 \mathrm{mM}$ DTE, $1 \mathrm{mM} \mathrm{NAD}{ }^{+}, 1 \mathrm{mM}$ ATP, protease inhibitor cocktail, and either $5 \mathrm{mM}$ EGTA (lane 8, EGTA) or $20 \mu \mathrm{M} \mathrm{CaCl}_{2}$ (lane 9, $\mathrm{CaCl}_{2}$ )

extensive cell budding with shedding of apoptotic bodies (Table 1), and acceleration of secondary necrosis with internucleosomal DNA fragmentation, inability to exclude trypan blue, swelling, and finally cell disruption.

Internucleosomal DNA fragmentation has traditionally been associated with apoptotic rather than necrotic cell death; so the above data are unusual by showing internucleosomal DNA fragmentation associated with secondary necrosis and not with the primary apoptosis. In other systems, cytoplasmic extract from apoptotic cells has been required to induce DNA fragmentation in nuclei isolated from nonapoptotic cells, ${ }^{18}$ but Orrenius et al. ${ }^{19}$ have demonstrated divalent metal-induced DNA fragmentation in isolated nuclei. We found strong internucleosomal DNA fragmentation in nuclei isolated from the hepatocytes when incubated for $1 \mathrm{~h}$ in a simple buffer with Mg/ATP. The DNA fragmentation was accelerated by, but not dependent on, the presence of $\mathrm{Ca}^{2+}$ (Figure 1, lanes 8 and 9). This shows that, at least in the nuclei of the presently studied hepatocytes, internucleosomal DNA cleavage can occur without the cytoplasmic or mitochondrially derived factors inducing DNA fragmentation in some apoptotic cells.

\section{Definition of the CaMKII-dependent commitment time points for cell budding, chromatin hypercondensation, secondary necrosis, and loss of capability for cell attachment and macromolecule synthesis}

Having established that MC was capable of inducing a number of morphological and functional parameters associated with apoptosis, next we wanted to know if CaMKII inhibitors could protect against all or only some of these parameters.

Cells preincubated with the CaMKII inhibitors KN62, KN93, or KT5926 were protected for at least $2 \mathrm{~h}$ against the appearance of the ultrastructural features accompanying apoptosis, like cytoplasmic and nuclear shrinkage, disappearance of microvilli, cell surface budding, and chromatin margination and hypercondensation, as shown in Table 1 for KN62. Glycogen degradation was not prevented (Table 1), suggesting that it was not coupled directly to apoptosis and could occur by an MC-activated mechanism not involving CaMKII.

To define the probable CaMKII-dependent commitment point for death, we needed CaMKII inhibitors able to rapidly enter the cells and block CaMKII-dependent protein phosphorylation. Both KT5926 (Figure 2) and KN93 (not shown) satisfied this criterion, being able to arrest the $\mathrm{MC}$-induced increase of protein phosphorylation when added to cells being incubated with a moderate concentration $(1 \mu \mathrm{M})$ of $\mathrm{MC}$. To ensure further the rapid cessation of MC-induced CaMKIIdependent hyperphosphorylation, the cells were diluted 20fold in MC-free medium with CaMKII inhibitor. Hepatocytes exposed to MC in the absence of CaMKII antagonist got evenly distributed minor blebs and buds, which eventually gathered at one pole of the cell (Figure $3 e$ and g) as polarized buds, typically with condensed actin at the base (Figure $3 \mathrm{f}$ and h). The $t_{0.5}$ for polarized budding was $19 \mathrm{~min}$ with $0.5 \mu \mathrm{M} \mathrm{MC}$ (Figure 3a). CaMKII inhibitor added 16-17 min after $0.5 \mu \mathrm{M}$ MC prevented half of the cells from budding (Figure 4a), suggesting that CaMKII activity was required until a few minutes before polarized budding. The exact same commitment time was noted for loss of plating ability (Figure 4b). Microscopic scrutiny in the early phase of plating revealed that no budded cells were able to plate. This suggested that polarized budding and loss of plating ability were coordinately regulated.

Chromatin hypercondensation occurred later than budding (Figure 3e-h), $t_{0.5}$ being $115 \mathrm{~min}$ (Figure 3b). The commitment point was at $40 \mathrm{~min}$ (Figure $4 \mathrm{c}$ ). This suggested that $0.5 \mu \mathrm{M}$ MC was required during $40 \mathrm{~min}$ to initiate, through a CaMKIIdependent pathway, a CaMKII-independent chain of events that led to visible chromatin hypercondensation more than $1 \mathrm{~h}$ later.

The cytoplasmic and nuclear volume started to decrease already after 2-3 $\mathrm{min}$ and the shrinkage was half-maximally complete after $9 \mathrm{~min}$ (Figure 5). Nuclear and cytoplasmic shrinkage occurred roughly in parallel, suggesting that depletion of water and associated solutes occurred near simultaneously from the nuclear and cytoplasmic compartments. Significant shrinkage was observed in cells that had not yet undergone polarized budding (inset of Figure 5a), 

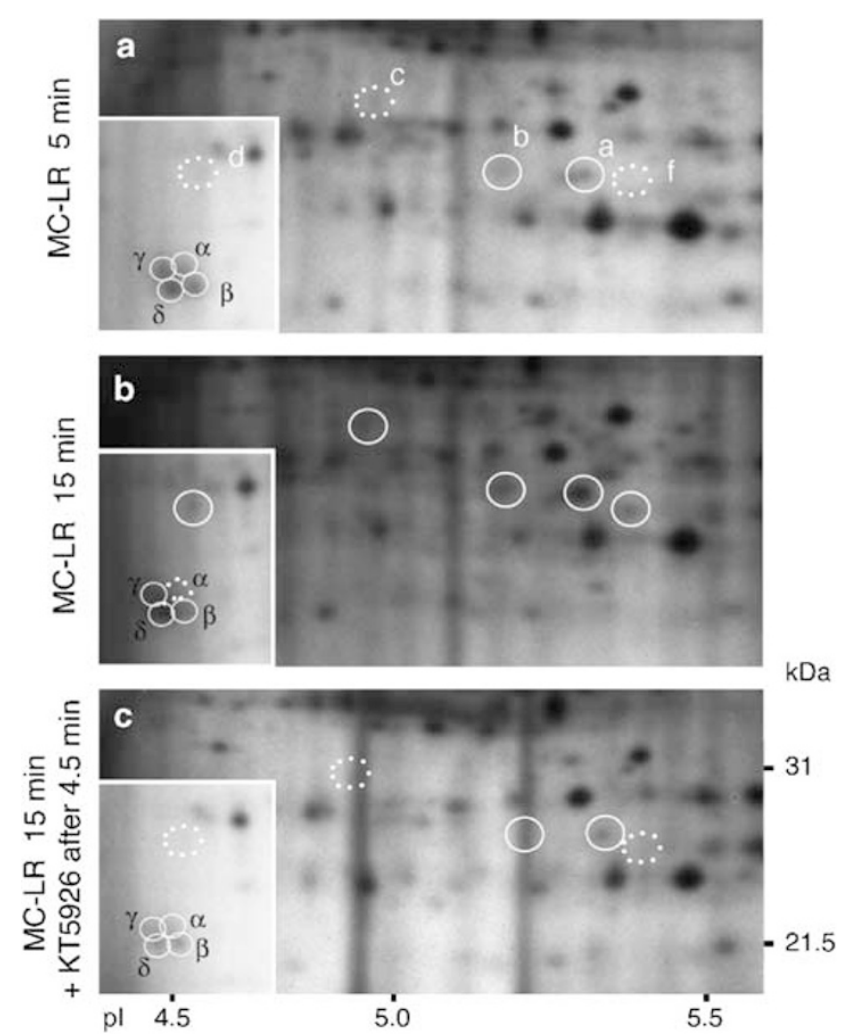

Figure 2 Addition of CaMKII inhibitor rapidly stops MC-induced protein phosphorylation in hepatocytes. Hepatocytes were prelabeled for $35 \mathrm{~min}$ with ${ }^{32} \mathrm{P}_{\mathrm{i}}$ before incubation for 5 min with $1 \mu \mathrm{M} \mathrm{MC}$ in the continued presence of ${ }^{32} \mathrm{P}_{\mathrm{j}}$. One aliquot was removed directly (a). Another aliquot was left for another $10 \mathrm{~min}$ with $\mathrm{MC}$ alone (b). A third aliquot was incubated for another $10 \mathrm{~min}$ with $\mathrm{MC}$ in the presence of $40 \mu \mathrm{M}$ of the kinase inhibitor KT5926 (c). The hepatocyte proteins were separated by 2D-electrophoresis and labeled protein spots visualized by autoradiography. The circles indicate ${ }^{32} \mathrm{P}$-labeled proteins present only in samples from hepatocytes treated with MC. When the spots were nonapparent, the circles are broken. Note that the increase in protein phosphorylation normally occurring between 5 and $15 \mathrm{~min}$ of exposure to $1 \mu \mathrm{M}$ MC was arrested by KT5926. For further details, see the Materials and Methods section

confirming that shrinkage preceded budding. The MCinduced cell shrinkage appeared to be reversible, since cells regained nearly their original volume when CaMKII inhibitor was added (not shown).

Results similar to those shown above were obtained when $\mathrm{MC}$ was replaced by nodularin or $\mathrm{KN} 93$ was replaced by KT5926 (not shown).

We next wanted to know the commitment point for loss of cell viability. Loss of viability was defined as irreversible loss of ability to synthesize macromolecules and development of secondary necrosis with cell disruption as the end stage. Cells having received $\mathrm{KN} 93$ at various time points after being challenged with $0.5 \mu \mathrm{M} \mathrm{MC}$ scored for budding and were left to attach on the plates. We noted an inverse correlation between budding and attachment (Figure 6a and b). Importantly, the attached cells treated with MC and then (from 20 min after MC addition) with KN93 (Figure 6d) were indistinguishable from the control cells (Figure $6 \mathrm{c}$ ) regarding general morphology. A normal proportion of such cells entered S-phase (range $35-45 \%$ labeled cells, $n=3$ ), as determined by $\left[{ }^{3} \mathrm{H}\right]$ thymidine labeling from 40 to $68 \mathrm{~h}$ after plating. The possibility remained that the nonattached, budded cells were still viable in the sense that they could synthesize, for example, protein. To test this possibility, hepatocytes, treated as for the experiment in Figure 6, were plated in the presence of $\left[{ }^{35}\right.$ S]methionine. The protein synthesis activity was defined as the ratio of incorporated $\left[{ }^{35}\right.$ S]methionine (Figure $7 \mathrm{~b}$ ) divided by the amount of protein (Figure 7a). Less than half the cells treated for 20 min with $0.5 \mu \mathrm{M} \mathrm{MC}$ were able to plate (Figure $6 \mathrm{~b}$ ), but these plated cells had nearly normal protein synthesis (Figure 7c). In contrast, the nonattached cells had lost more than $80 \%$ of synthetic activity compared to control cells (Figure 7c). More than 95\% of the protein synthesis activity was lost in nonattached cells pretreated with $2 \mu \mathrm{M}$ of $\mathrm{MC}$ for 24 min before addition of KN93 (Figure 7b and c). The lack of plating could not in itself explain the low protein synthesis, since untreated cells kept in suspension incorporated $\left[{ }^{35}\right.$ S]methionine into protein (data not shown).

All the nonattached cells eventually underwent secondary necrosis with influx of trypan blue, swelling of the mitochondria, and gross degradation of DNA, culminating in cell disruption (not shown). We conclude that PP inhibitors could commit the cells not only to irreversible loss of ability to synthesize proteins and DNA, but also to eventually become necrotic. The CaMKII-dependent commitment point for all these events was similar to that for induction of polarized cell budding and cell plating, and preceded the commitment for chromatin hypercondensation.

\section{The effect of the caspase inhibitor Z-VAD and the antioxidant naringin on MC-induced apoptosis}

The CaMKII-dependent commitment point occurred a few minutes before execution in the case of budding and more than an hour earlier in the case of chromatin hypercondensation (see above). This suggested that CaMKII had stimulated the production of a rather long-lived metabolite (second messenger) and/or irreversibly activated the function of a proapoptotic macromolecule. Obvious candidates are caspase activation or production of reactive oxygen species (ROS), since the caspase inhibitor Z-VAD and antioxidants, including the flavinoid naringin, ${ }^{20}$ can counteract PP-inhibitor effects on hepatocytes. ${ }^{10,15,21}$

We compared first the ultrastructure of hepatocytes treated for $30 \mathrm{~min}$ with $0.5 \mu \mathrm{M} \mathrm{MC}$ in the absence and presence of $z$ VAD. Most stages of MC-induced apoptosis were observed also in the presence of $z-V A D$, but the less advanced stages predominated (Figure 8). This suggested that the z-VADsensitive proteases acted to moderately accelerate rather than modify the apoptotic process. Since z-VAD, unlike CaMKII antagonists, was an incomplete inhibitor of the apoptosis, no caspase-dependent commitment point could be defined.

In contrast, the antioxidants $N$-acetylcysteine $(5 \mathrm{mM})$, Tempol $(7.5 \mathrm{mM})$, or naringin $(0.1 \mathrm{mM})$, given $15 \mathrm{~min}$ before $0.5 \mu \mathrm{M} \mathrm{MC}$, decreased the MC-induced apoptosis after $45 \mathrm{~min}$ from $93-96$ to $13-17,8-10$, and 1-2\%, respectively (range $n=3$ ). When naringin was added simultaneously with MC, it was as efficient as KN93 in preventing hepatocyte budding 
a
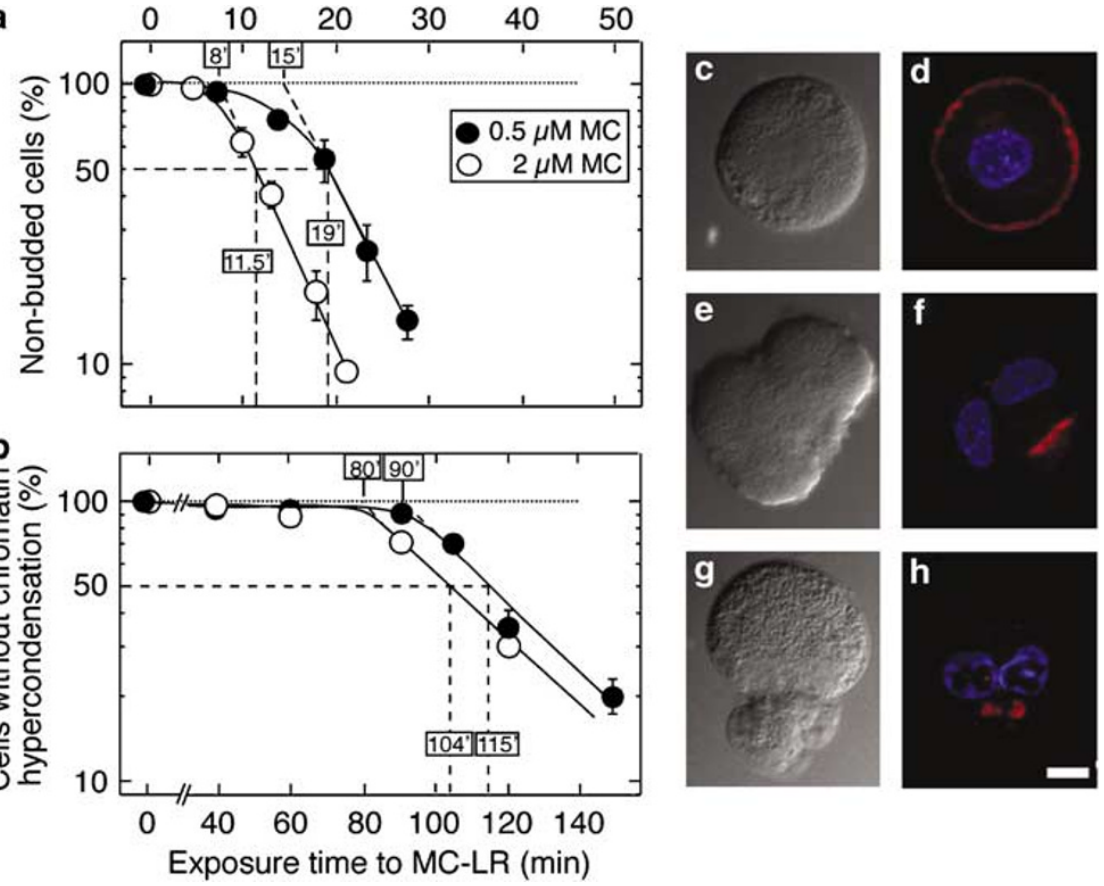

Figure 3 The sequential appearance of apoptotic features in hepatocytes after exposure to $\mathrm{MC}$. Hepatocytes in suspension were treated with $0.5 \mu \mathrm{M}(\bullet)$ or $2.0 \mu \mathrm{M}$ (O) MC, and aliquots fixed for microscopic assessment of (a) surface budding and (b) chromatin hypercondensation, as described in the Materials and Methods section. The data were plotted semilogarithmically to be able to calculate the rate constant of budding $\left(k=0.17 \mathrm{~min}^{-1}\right.$ for $0.5 \mu \mathrm{M}$ and $k=0.19 \mathrm{~min}^{-1}$ for $\left.2 \mu \mathrm{M} \mathrm{MC}\right)$ and the average time of onset of budding ( $T_{\text {lag }}=15 \mathrm{~min}$ for $0.5 \mu \mathrm{M}$ and $T_{\text {lag }}=8 \mathrm{~min}$ for $2 \mu \mathrm{M} \mathrm{MC}$; shown in the boxes on top as the time where the extrapolated first-order line hits the $100 \%$ mark). Half the population had started budding after $11.5 \mathrm{~min}$ with $2 \mu \mathrm{M} \mathrm{MC}$ and $19 \mathrm{~min}$ with $0.5 \mu \mathrm{M} \mathrm{MC}$. Similarly, for chromatin hypercondensation (b), the $k$ value was $0.030 \mathrm{~min}^{-1}$ for both 0.5 and $2 \mu \mathrm{M} \mathrm{MC}$, whereas the $T_{\text {lag }}$ was 90 and $80 \mathrm{~min}$, respectively. Half of the cells had hypercondensed chromatin after 115 min $(0.5 \mu \mathrm{M} \mathrm{MC})$ or $104 \mathrm{~min}(2 \mu \mathrm{M} \mathrm{MC})$. Control hepatocytes had smooth surface (c), actin in the whole periphery of the cell (d), and normal chromatin staining (d). A typical (binuclear) cell incubated for 20 min with $0.5 \mu \mathrm{M} \mathrm{MC}$ had early polarized budding (e) with condensation of actin at its base (f), but no chromatin hypercondensation (f). After 120 min of incubation, nearly all cells showed pronounced polarized budding (g) with hypercondensed actin and chromatin (h). Bar, $5 \mu \mathrm{m}$. The data represent the mean \pm S.E.M. $(n=3-7$ separate experiments)

and chromatin condensation (Figure 9). Naringin could inhibit the polarized budding until just before it occurred (Figure 9), that is, slightly after the commitment point for CaMKII (Figures 4 and 9). Naringin could protect from chromatin condensation until $70 \mathrm{~min}$ after $\mathrm{MC}$, that is, $30 \mathrm{~min}$ after the CaMKII commitment point (Figures 4 and 9). We conclude that antioxidant, but not z-VAD, could protect cells that had passed the CaMKII-dependent commitment point, compatible with ROS actions persisting after the CaMKII activity had been inhibited.

\section{Discussion}

Active CaMKII was required for all the apoptotic parameters observed in MC-treated hepatocytes (Table 1, Figures 2, 4, 6 and 7). By analyzing the fate of cells diluted in MC-free medium with CaMKII antagonist we could determine the commitment points for the various indices of $\mathrm{MC}$-induced death. We defined a time point of ' $50 \%$ no return' about $15-$ $17 \mathrm{~min}$ after the addition of $0.5 \mu \mathrm{M} \mathrm{MC}$. At this point the cells became committed to lose the ability to synthesize protein and DNA and to attach to the substratum, and also became committed to undergo DNA fragmentation and cell swelling, eventually leading to cell disruption.
To our surprise, two of the four prime parameters of apoptotic cell death, as originally defined, ${ }^{22,23}$ that is, cell shrinkage and chromatin hypercondensation, had commitment points that failed to coincide with that for 'death' itself. Cytoplasmic and nuclear shrinkage commenced a few minutes after addition of $\mathrm{MC}$ and was significant also in nonbudding cells not yet committed to death. Cell shrinkage was therefore insufficient to commit the cells to death. Shrinkage had, unlike death, no defined commitment point, being reversible upon blocking of the CaMKII activity. Apparently, continuous CaMKII activity was required to maintain the shrunken state. Uncoupling between shrinkage and death has been suggested also in studies using manipulation of medium ion composition and of ion channel function to dissociate the control of cell volume and cell death. $^{24}$

The commitment for chromatin hypercondensation occurred about $20 \mathrm{~min}$ after the cells had been irreversibly committed to die. Chromatin condensation was therefore an epiphenomenon not directly related to the death pathway of MC action. In a study of caspase-independent staurosporineinduced T-lymphocyte death, cells that had moderate chromatin condensation could be rescued and the chromatin condensation reversed by removal of staurosporine. ${ }^{25}$ Although chromatin condensation was an early event in 

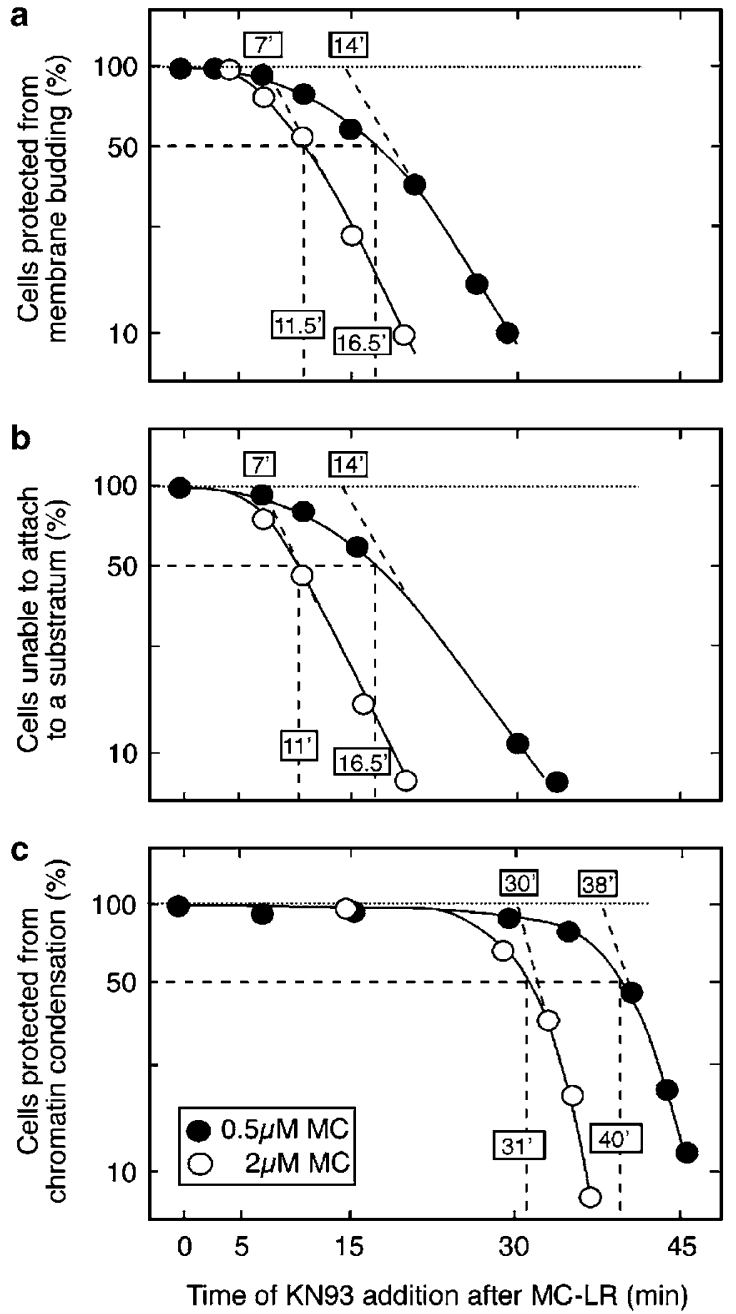

Figure 4 Determination of the point when CaMKII activity is no more required for the progression of various $\mathrm{MC}$-induced cell death-associated parameters. Hepatocytes in suspension culture were incubated with $0.5(0)$ or $2.0 \mu \mathrm{M}(\mathrm{O})$ of MC. After various incubation periods (2-45 min), a 20 -fold excess of medium containing $30 \mu \mathrm{M}$ of the CaMKII antagonist KN93 was added in order to abruptly inhibit the CaMKII activity. The incubation was continued until 45 min after the addition of MC, when the cells were washed and resuspended in fresh medium containing $3 \mu \mathrm{M} \mathrm{KN93}$. The washed cells from each condition were fixed for evaluation of surface budding (a), plated on tissue culture dishes and assessed for ability to attach (b), or left for another $1.5 \mathrm{~h}$ before fixation for morphological assessment of chromatin hypercondensation (c). The $T_{\text {lag }}$ (see the boxes on top) and the time for $50 \%$ commitment are indicated by dashed lines (see the legend to Figure 3 and the Materials and Methods section for further details). The results shown are from a typical experiment when all three parameters (budding, plating, and chromatin hypercondensation) were determined

staurosporine-induced death and a late event in MC-induced death, the report ${ }^{25}$ supports our conclusion that chromatin condensation can be dissociated from the commitment to death.

The CaMKII-dependent commitment point for polarized budding and loss of plating ability coincided with that for 'death'. While budding occurred only a few minutes after the commitment point, secondary necrosis and DNA fragmentation occurred hours later. This suggested that $\mathrm{MC}$, via CaMKII, had initiated events that could affect many different cell constituents and functions and had long-term impact on
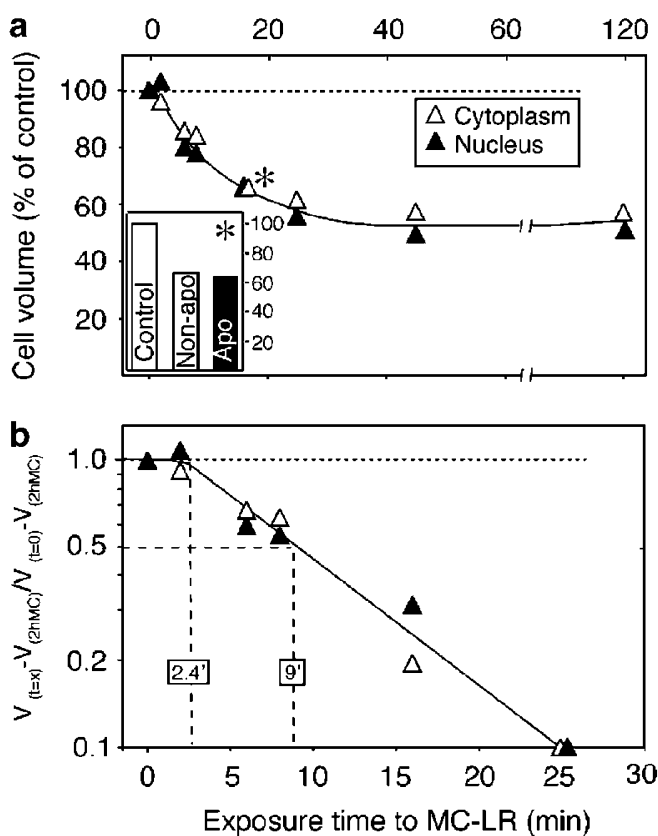

Figure 5 Cytoplasmic and nuclear shrinkage occurs early after exposure of hepatocytes to MC. The relative cytoplasmic and nuclear volumes were determined as described in the Materials and methods section. Panel a shows the cytoplasmic $(\Delta)$ and nuclear volume $(\mathbf{\Delta})$ plotted as \% of control volume against time of incubation with $0.5 \mu \mathrm{M} \mathrm{MC}$. The inset shows the volume decrease (units on the right ordinate give cell volume as $\%$ of control cells) for cells with cell budding and without cell budding after 16 min of incubation with MC. It shows that nonbudding (preapoptotic) cells had about the same column decrease as budding (apoptotic) cells. In order to calculate the rate of the volume decrease related to the maximal decrease (panel $\mathrm{b}$ ), the volume after $2 \mathrm{~h}$ incubation with $2 \mu \mathrm{M} \mathrm{MC}$, that is, $V(2 \mathrm{hMC})$, was determined (not shown), and taken as the end point of volume decrease. The fraction $V(t=x)-V(2 \mathrm{hMC}) / V(t=0)-V(2 \mathrm{hMC})$ tells how much of the maximal volume decrease has been reached after time $=X$, and was plotted (note log scale) in panel $b$ against time of incubation with $0.5 \mu \mathrm{M} \mathrm{MC}$. From this plot it is apparent that cytoplasmic and nuclear shrinkage commenced after 2-3 min of incubation and that half of the shrinkage occurred during the first 9 min of incubation

the cell even in the absence of continued CaMKII activity. In many cell models, the 'commitment to die' has been defined to be the moment when caspases have become activated. ${ }^{26,27}$ An obvious explanation was therefore that MC, via CaMKII, had activated caspase-initiated cascades that after latency led to budding, loss of protein synthesis, and DNA fragmentation. Apoptosis was, however, merely moderately delayed in the presence of caspase inhibitor (Figure 8). We propose therefore that caspase activation is probably an amplification loop for MC-induced apoptosis rather than an obligate effector of CaMKII action. This is in line with the role of caspase in fibroblast apoptosis induced by DNA damage, ${ }^{28}$ and for PP. inhibitor-induced apoptosis in fibroblasts ${ }^{29}$ and MCF-7 cells. ${ }^{10}$

Another candidate for a downstream effector of CaMKII is ROS. The accumulation of ROS can occur within minutes in MC-treated hepatocytes. ${ }^{15}$ We found that the antioxidant naringin could protect cells even when given after the CaMKIIdependent commitment point. This suggests that CaMKII acts upstream of ROS. In line with this, naringin was found to only marginally affect the protein phosphorylation in okadaic acidstimulated hepatocytes. ${ }^{30}$ Furthermore, hepatocytes stimulated by ROS generators like azide fail to reproduce the 

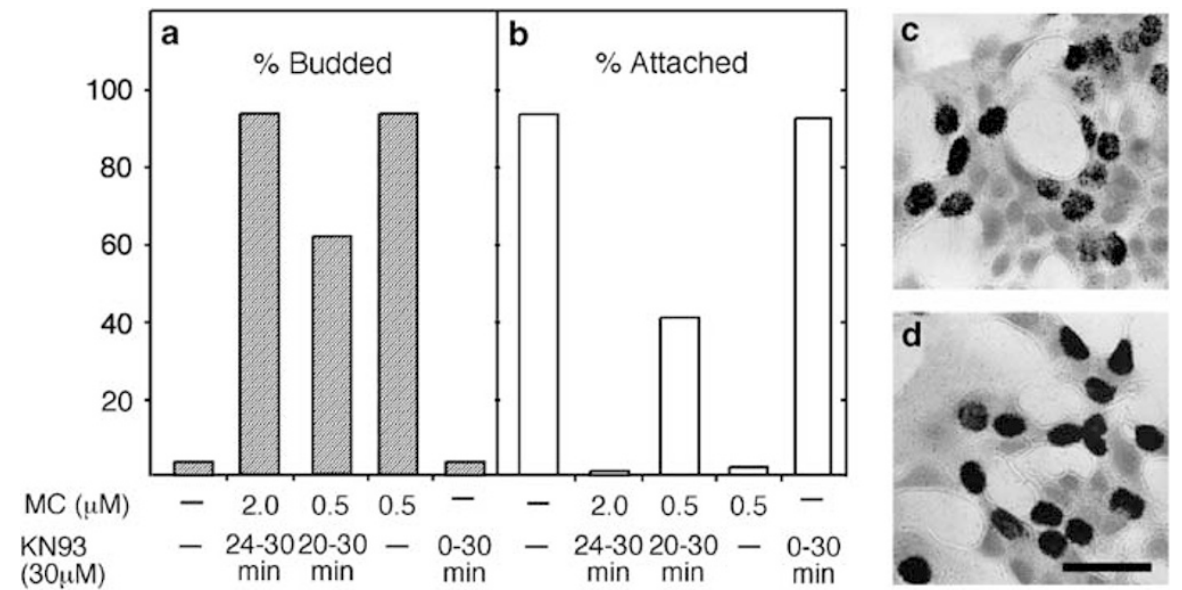

Figure 6 The commitment to cell budding coincides with loss of capability for substrate attachment. Attached cells treated with MC and KN93 have DNA replicative capacity. Hepatocytes were incubated for $30 \mathrm{~min}$ in the absence or presence of $\mathrm{MC}(0.5$ or $2 \mu \mathrm{M})$. The incubations were diluted 25 -fold in medium with $30 \mu \mathrm{M} \mathrm{KN93}$ to arrest the CaMKII-dependent activity after various periods of incubation. At $30 \mathrm{~min}$ after the addition of MC, the cells were washed, plated on collagen-coated tissue culture dishes in medium with $3 \mu \mathrm{M} \mathrm{KN93}$, and left to adhere to the substratum for $6 \mathrm{~h}$. The percentage of budded (a) and adherent (b) cells was determined. The control cells were diluted 25 -fold in medium with KN93 after 30 min of incubation without MC and immediately washed and plated as described above. They showed less than $5 \%$ budding (a, left column) and $85 \%$ attachment (b, left column). The nonbudded, nonattached cells (10\% of the population) failed to exclude trypan blue and were considered necrotic (not shown). Similar results were observed for control cells diluted 25-fold in medium with KN93 and kept for 30 min before washing (a, b, right columns). Cells incubated with $0.5 \mu \mathrm{M} \mathrm{MC}$ for 30 min before dilution in medium with KN93 followed by washing showed $90 \%$ budding and nearly no attachment (a, b, column 4). Similar results were obtained for cells diluted in KN93-containing medium after 24 min of incubation with $2 \mu \mathrm{M} \mathrm{MC} \mathrm{(a,} \mathrm{b,} \mathrm{column} \mathrm{2).} \mathrm{In} \mathrm{contrast,} \mathrm{30-40 \%} \mathrm{of} \mathrm{the}$ cells were protected against budding (a, column 3 ) and able to attach (b, column 3) when KN93 was added after 20 min of incubation, suggesting that about $35 \%$ of the cells had not yet been committed to bud and fail to attach after 20 min incubation with $0.5 \mu \mathrm{M} \mathrm{MC}$. The adherent cells from the latter incubation showed neither budding nor necrosis, and had similar morphology (d) as attached control cells. They had also similar percentage (38 and $37 \%$, respectively) of cells that had entered DNA replication from 40 to $68 \mathrm{~h}$ after seeding, as judged by the number of nuclei with incorporation of $\left[{ }^{3} \mathrm{H}\right]$ thymidine in autoradiographs (c, d). The results are from a typical experiment, the same as shown in Figure 7. Bar is $50 \mu \mathrm{m}$

MC-induced phosphoprotein pattern or death phenotype (C Krakstad, BT Gjertsen and SO Døskeland, unpublished observations). This suggests that MC-induced activation of CaMKII induces death not only through ROS formation, but also through other phosphorylation events (see Figure 10 for an overview). One such event may be the increased myosin light chain (MLC) phosphorylation (Figure 2; see also Fladmark et al. ${ }^{10}$ ). MLC phosphorylation by the MLC kinase has been implicated in the formation of cell buds, ${ }^{31}$ and can be CaMKII-dependent since CaMKII activates the MLC kinase. ${ }^{32}$ The phosphorylation of MLC was not affected by antioxidants ( $\mathrm{T}$ Solstad and K Fladmark, unpublished observations), suggesting that it occurred upstream and independently of ROS formation. The intermediary filament network collapses when cytokeratins 8 and 18 are phosphorylated by CaMKII in intact cells treated with PP inhibitors. ${ }^{8,21}$ Similar phosphorylation events occur in hepatocytes incubated with $30 \mathrm{nM}$ okadaic acid, ${ }^{21}$ at which concentration okadaic acid is nonapoptogenic. ${ }^{4,21}$ The effects of MC on the intermediary filaments are therefore probably not causing the cell death.

Important mechanistic questions relate to the activation of $\mathrm{CaMKII}^{33}$ and the accumulation of $\mathrm{ROS}^{15}$ in PP-inhibitortreated hepatocytes. Three alternative ways of activating CaMKII have been proposed. One is through caspase cleavage removing the autoinhibitory domain. ${ }^{14}$ This was unlikely to be a major factor in our hepatocyte system, since caspase inhibitor failed to modify the bulk of the CaMKIIdependent phosphorylation events induced by PP inhibitor ${ }^{10}$ and only partly protected against $\mathrm{MC}$-induced death under the present experimental conditions (Figure 8). Another possibility is through oxidative damage of mitochondria leading to early $\mathrm{Ca}^{2+}$ efflux and thereby activation of CaMKII by $\mathrm{Ca}^{2+}$ / calmodulin before the commitment point for death. This is an attractive hypothesis since it can explain why antioxidants can abrogate PP-inhibitor-induced hepatocyte death. ${ }^{15,16,21} \mathrm{We}$ were unable to prevent $\mathrm{MC}$-induced hepatocyte apoptosis using $\mathrm{Ca}^{2+}$ chelators, suggesting that $\mathrm{Ca}^{2+}$ did not have any role in the early purely apoptotic phase of MC-induced hepatocyte death. We failed, furthermore, to observe any gross ultrastructural damage or swelling of mitochondria in hepatocytes treated with $\mathrm{MC}$ for $2 \mathrm{~h}$ (Table 1) or $20 \mathrm{~min}$ (Figure 8).

The inability of $\mathrm{Ca}^{2+}$ chelators to prevent MC-induced apoptosis may be puzzling in view of the role of the $\mathrm{Ca}^{2+}$ / calmodulin-dependent protein kinase II in the process. It should be noted, however, that, when autophosphorylated on a critical threonine residue, the CaMKII has 1000-fold increased affinity for $\mathrm{Ca}^{2+}$ /calmodulin and is active even in the absence of $\mathrm{Ca}^{2+} /$ calmodulin (for recent reviews, see Colbran $^{13}$ and Hudmon and Schulman ${ }^{34}$ ). Since phosphoprotein phosphatase type 2A (PP2A) and phosphoprotein phosphatase type 1 (PP1) catalyze the dephosphorylation of autoactivated CaMKII, ${ }^{13,35}$ an obvious pathway for PPinhibitor activation of CaMKII is by blocking its dephosphorylation, ${ }^{33}$ thereby circumventing the need for increased $\mathrm{Ca}_{i}^{2+}$. Recently, Howe et al. ${ }^{36}$ have shown that reactive oxygen radicals can inactivate PP2A and thereby stimulate CaMKII. This suggests that MC, by inhibition of PP and activation of CaMKII, can increase the accumulation of ROS, which by inhibition of PP2A ${ }^{36}$ can lead to further PP inhibition and activation of CaMKII. This provides an attractive amplification loop for CaMKII activation in stressed cells (Figure 10), and 

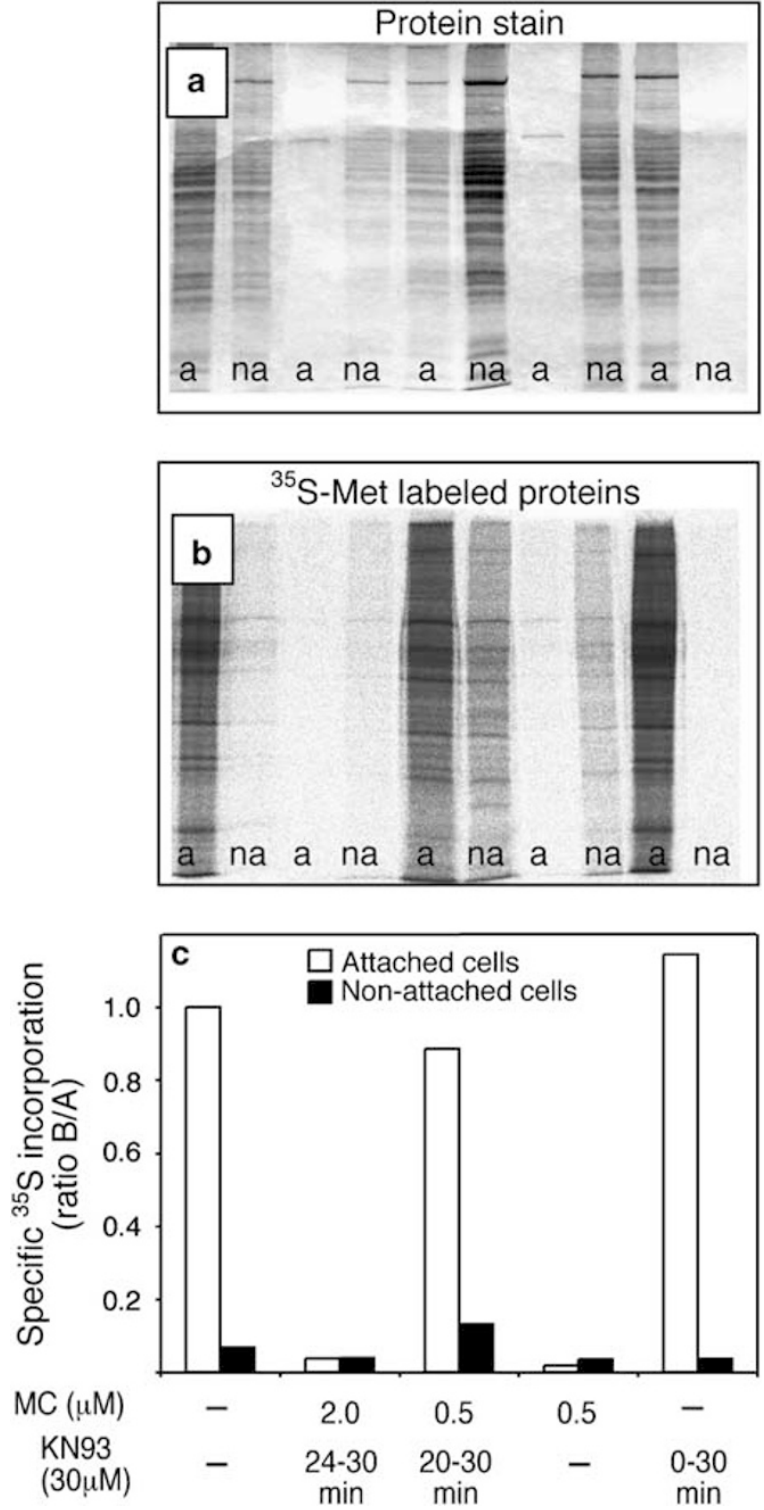

Figure 7 The loss of cell capability for substrate attachment coincides with loss of protein synthesis. Cells were treated as described in the legend to Figure 6 , but plated with medium containing $\left[{ }^{35} \mathrm{~S}\right]$ methionine. After $6 \mathrm{~h}$, the attached and nonattached cells in each well were collected, lyzed, and the proteins in the lysate separated by SDS-gel electrophoresis. The gels were stained with Coomassie brilliant blue for general protein content (a) and analyzed by autoradiography for proteins with incorporated $\left[{ }^{35}\right.$ S]methionine (b). The ratio of the autoradiographic intensity to the general protein-staining intensity was taken as a measure of the protein synthesis activity (c). Data are presented for the attached (a) and nonattached (na) cells

Figure 8 Comparison of the morphology of hepatocytes treated with MC in the absence and presence of the caspase inhibitor ZVAD-fmk. Hepatocytes were incubated for $20 \mathrm{~min}$ with $0.5 \mu \mathrm{M} \mathrm{MC}$ in the absence $(\mathbf{c}-\mathbf{g})$ and presence $(\mathbf{h}-\mathbf{m})$ of the caspase inhibitor ZVAD-fmk, which was added $30 \mathrm{~min}$ before MC. The cells were prepared for TEM as described in the Materials and Methods section. The cells are shown in various stages of reaction towards $\mathrm{MC}$ in the order in which they appeared after MC addition (as determined in separate experiments not shown). Note also that the mitochondrial morphology in cells with advanced polarized budding (f) was similar to that of control cells (b, a), so the apoptosis judgement was based on low-magnification ultramicrographs. The percentage of cells with each type of morphology is indicated in insets. Note that the morphologies are similar with and without zVAD, but that earlier stages predominate with ZVAD. Bar $5 \mu \mathrm{m}$ for all panels except (b) and (f), where it is $0.5 \mu \mathrm{M}$

\section{Control}
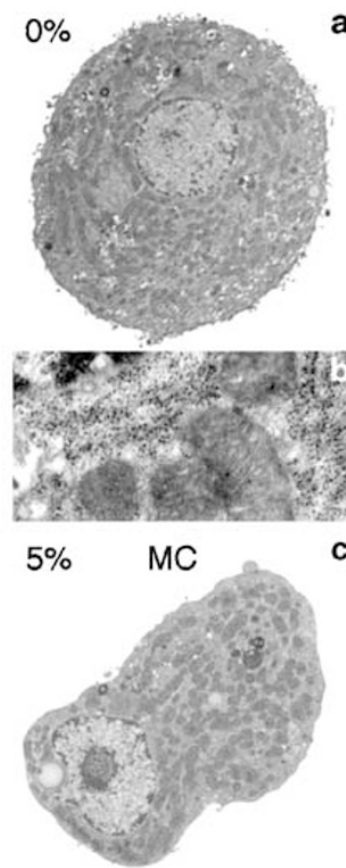

$30 \%$

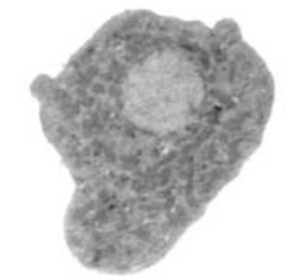

$10 \%$

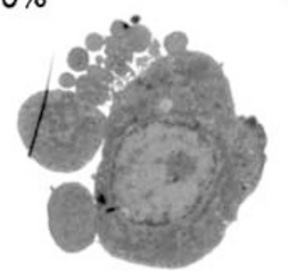

d

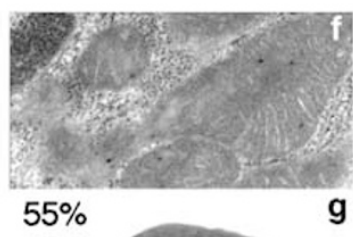

e

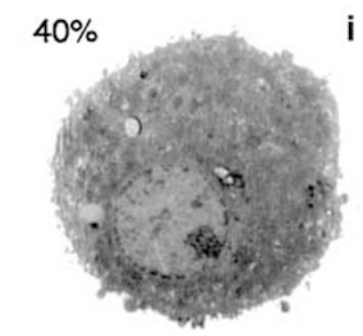

$30 \%$

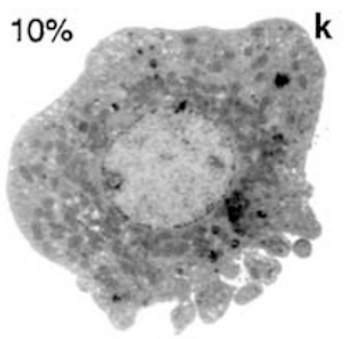

$5 \%$

$5 \%$

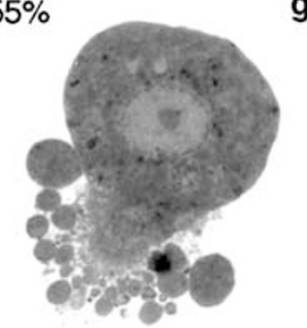

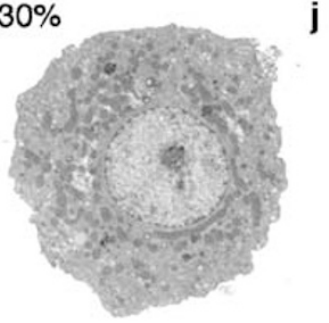

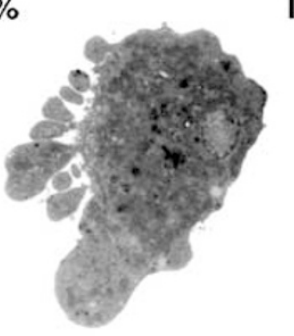

m

h

i

j

I

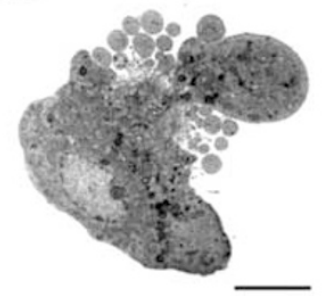




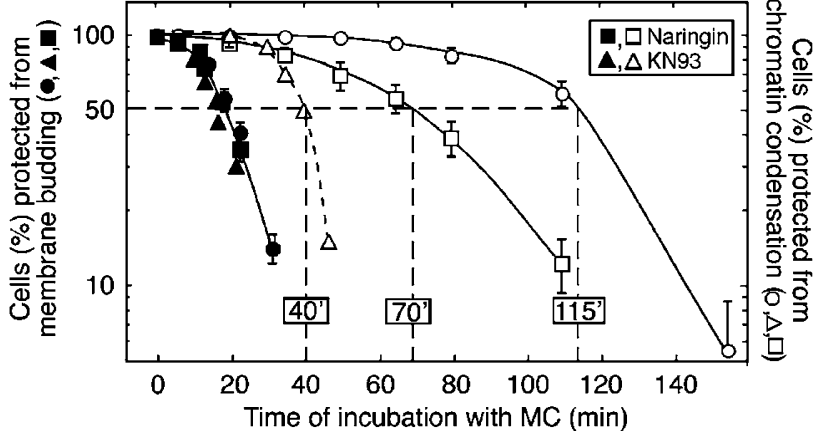

Figure 9 Comparison of the commitment points for budding and chromatin condensation, as probed by CamKII inhibitor and antioxidant. Hepatocytes were incubated with $0.5 \mu \mathrm{M} \mathrm{MC}$. After various periods of time (abscissa), cell samples were withdrawn, fixed, and assessed for polarized budding $(\mathbf{O})$ and chromatin condensation $(\bigcirc)$, as described in the legend to Figure 4. At the same time points, similar cell samples were diluted 25-fold in MC-free medium with $30 \mu \mathrm{M}$ of the CaMKII inhibitor KN93 $(\triangle, \boldsymbol{\Delta})$ or $0.1 \mathrm{mM}$ of the antioxidant naringin $(\square, \boldsymbol{\square})$ The cells in such samples were assessed for polarized budding (closed symbols) and chromatin condensation (open symbols) $150 \mathrm{~min}$ after the addition of MC. Note that the addition of naringin appeared to stop the development of budding in less than $2 \mathrm{~min}$, since there was hardly any increase of budding after its addition $(\boldsymbol{\square})$, as compared to samples directly fixed at the time of naringin addition $(\boldsymbol{O})$. Similarly, KN93 $(\boldsymbol{\Delta})$ apparently needed only about 2 min to block the further development of budding. To prevent chromatin condensation, KN93 had to be added $75 \mathrm{~min}\left(115^{\prime}-40^{\prime}\right)$ before it occurred $(\triangle)$, while naringin must be present $45^{\prime}\left(115^{\prime}-70^{\prime}\right)$ before chromatin condensation $(\square)$. The data represent the mean \pm S.E.M. $(n=3-5$ separate experiments)

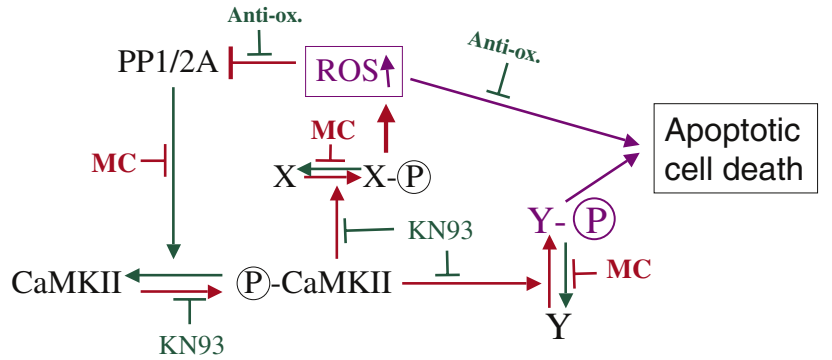

Figure 10 Proposed role of CaMKII in MC-induced apoptosis in primary rat hepatocytes. The scheme shows a proposed positive feedback loop for CaMKII activation and ROS formation based on PP inhibition and CaMKII activation by both MC and ROS. The scheme suggests that the rapid and efficient apoptosis induced by MC depends on both putative phosphorylation events catalyzed by CaMKII $(Y)$ and as yet unidentified effects of ROS

may explain why ROS-inducing gamma irradiation and okadaic acid both lead to CaMKII-dependent Jurkat cell apoptosis. $^{3}$

The MC-induced death had two stages. The first stage was characterized by polarized budding, and pronounced shrinkage with apparently intact DNA and mitochondria (Table 1, Figures 1 and 8). The second stage occurred much later and included secondary necrosis-like features like cell and mitochondrial swelling, inability to exclude trypan blue, and extensive DNA degradation. In cells with a low energy store, the DNA fragmentation and signs of necrosis, like mitochondrial swelling and inability to exclude trypan blue, occurred early. The present study using freshly isolated hepatocytes in suspension culture failed to find swollen mitochondria (Table 1, Figure 8) or DNA fragmentation (Figure 1) during the early phase of incubation with $\mathrm{MC}$. Other studies, using hepatocytes in monolayer, noted early DNA fragmentation, cell permeability, and mitochondrial dysfunction in MCinduced death. ${ }^{15-17}$ The reason for this discrepancy is not clear. It is well known that death-inducing agents, like TNF- $\alpha$, which also stimulates ROS formation, can induce either apoptosis or necrosis depending both on cell type and the physiological conditions. ${ }^{37}$

In conclusion, we have shown that hepatocytes have a common CaMKII-dependent commitment point for 'death' coinciding with the formation of polarized cell buds, and dissociated from both chromatin condensation and cell shrinkage. The CaMKII-dependent commitment point precedes a putative ROS commitment point, suggesting that CaMKII activation can occur upstream of ROS formation.

\section{Materials and Methods}

MC, bisbenzimide (Hoechst 33342), KN93, and QUIN 2/AM were from Calbiochem (La Jolla, CA, USA). KT5926 was from Kamiya Biomedical Co. (Thousand Oaks, CA, USA). KN62 was from Seikagaku America, Inc. (Rockville, MD, USA). N-acetyl-cysteine, BAPTA (1,2-bis(O-aminophenoxyl)ethane- $N, N, N, N$-tetracetic acid tetra(acetoxymethyl)ester), naringin, and TEMPOL (4-hydroxy-2,2,6,6-tetramethylpiperidine-1-oxyl) were from Sigma-Aldrich, St Louis, MO, USA. Vitrogen $100^{\mathrm{TM}}$ (composed of $95 \%$ type I and 5\% type III collagen) was from The Collagen Corporation (Palo Alto, CA, USA). Pharmalyte and linear immobilized pH 4.0-7.0 gradients were from Pharmacia Biotechnology (Uppsala, Sweden).

\section{Cell culturing; determination of cell attachment, protein synthesis, DNA replication, and fragmentation}

Hepatocytes were isolated from male Wistar rats (120-200 g) by in vitro collagenase perfusion, and either kept in suspension or cultured on collagen gel, as described previously. ${ }^{38}$ For short-term suspension cultures, hepatocytes were resuspended $\left(1.2 \times 10^{6} \mathrm{cells} / \mathrm{ml}\right)$ in pregassed $\left(95 \% \quad \mathrm{O}_{2} / 5 \% \quad \mathrm{CO}_{2}\right)$ low-phosphate incubation buffer $(10 \mathrm{mM}$ Hepes, pH 7.4, with $120 \mathrm{mM} \mathrm{NaCl}, 5.3 \mathrm{mM} \mathrm{KCl}, 0.01 \mathrm{mM} \mathrm{KH}_{2} \mathrm{PO}_{4}, 1.2 \mathrm{mM}$ $\mathrm{MgSO}_{4}, 1.0 \mathrm{mM} \mathrm{CaCl}_{2}, 5 \mathrm{mM}$ lactate, $5 \mathrm{mM}$ pyruvate, and $0.5 \%$ bovine serum albumin). The incubation was in capped vials with gyratory shaking (175 cycles $/ \mathrm{min}, 37^{\circ} \mathrm{C}$ ).

We observed that hepatocytes from fasted animals reacted more slowly to $\mathrm{MC}$, and in some cases underwent cell swelling rather than shrinkage, rapidly becoming trypan blue positive. Hepatocytes isolated from fed rats later during the day, when the liver glycogen is expected to decrease since rats are nocturnal feeders, also tended to become more necrotic. We performed therefore all the experiments with hepatocytes isolated early in the morning from well-fed animals.

To study the ability to attach to substratum, and the activity of protein synthesis and DNA replication, the hepatocytes (120000 cells per well) were seeded in six-well dishes precoated with collagen, as described previously, ${ }^{38}$ except that the medium was sometimes methionine-free to allow the assessment of protein synthesis by incorporation of exogenously added $\left[{ }^{35}\right.$ S]methionine. The $\%$ attachment of the seeded hepatocytes was determined by microcopy $6 \mathrm{~h}$ after seeding. Gentle tapping on the dish revealed that all attached cells had a flattened shape, whereas all round cells were nonattached. When the nonattached cells were gently withdrawn by suction of the medium, only rounded cells were recovered, 
and only flattened cells remained in the dish. The number of attached cells having entered S-phase between 40 and $68 \mathrm{~h}$ after seeding was determined by labeling the cells with $\left[{ }^{3} \mathrm{H}\right]$ thymidine $\left(1.5 \mu \mathrm{Ci} / 10 \mathrm{~cm}^{2}\right.$ dish) from 40 to $68 \mathrm{~h}$ after seeding, and counting the number of labeled and unlabeled nuclei after autoradiography. To optimize the medium and boost proliferation, the cells were given $0.2 \mathrm{nM}$ insulin and $5 \mathrm{nM}$ dexamethasone $6 \mathrm{~h}$ after seeding and supplemented with $9 \mathrm{nM}$ epidermal growth factor $20 \mathrm{~h}$ after seeding.

To determine protein synthesis activity, the detached cells were centrifuged $(400 \times g, 2 \mathrm{~min})$, resuspended in fresh medium containing $\left[{ }^{35} \mathrm{~S}\right]$ methionine, and left for $90 \mathrm{~min}$ in a collagen-coated well. The attached cells were also incubated with the $\left[{ }^{35} S\right]$ methionine-containing medium for $90 \mathrm{~min}$. Each well contained $0.5 \mathrm{ml}$ medium with $8 \mu \mathrm{Ci}\left[{ }^{35} \mathrm{~S}\right]$ methionine. The incubation was terminated by the addition of ice-cold $7 \%$ aqueous trichloroacetic acid. The cell precipitates were transferred to tubes, centrifuged $(15000 \times \mathrm{g}, 15 \mathrm{~min})$, and the pellet washed three times in 5\% trichloroacetic acid and twice in diethyl ether, before dissolving in SDS loading buffer (50 mM Tris-HCl, pH 6.8, 10\% glycerol, 2\% SDS, $100 \mathrm{mM}$ DTT and $0.05 \%$ bromophenol blue). The samples were electrophoresed on $12.5 \%$ acrylamide ( $12 \%$ acrylamide, $0.2 \%$ bisacrylamide). The gels were strained for protein with Commassie brilliant blue, dried and subjected to quantitative autoradiography after 1-2 weeks exposure using the Fuji BAS 5000 system. The protein staining intensity was determined by scanning the stained gel and analysis on the Fuji LAS 1000 system.

Hepatocyte nuclei were prepared from isolated rat hepatocytes. The cells $\left(2 \times 10^{7}\right)$ were transferred to ice-cold TKM buffer $(50 \mathrm{mM}$ Tris- $\mathrm{HCl}$, $25 \mathrm{mM} \mathrm{KCl}, 5 \mathrm{mM} \mathrm{MgCl}_{2}, \mathrm{pH} 7.45$ ) with $0.25 \mathrm{M}$ sucrose, and homogenized by being forced eight times between a metal bullet with diameter $8.004 \mathrm{~mm}$ and a cylindrical metal wall of diameter $8.02 \mathrm{~mm}$. One volume of homogenate was mixed with two volumes of TKM/2.1 M sucrose, layered over $\mathrm{TKM} / 2.1 \mathrm{M}$ sucrose, and centrifuged at $50000 \times g_{\mathrm{av}}$ for $2 \mathrm{~h}$. The pellet, containing isolated nuclei, was resuspended in $0.1 \mathrm{ml}$ of ice-cold $\mathrm{TKM} / 0.25 \mathrm{M}$ sucrose, diluted in $2 \mathrm{ml}$ of $25 \mathrm{mM}$ Hepes, with $125 \mathrm{mM} \mathrm{KCl}$, $2 \mathrm{mM} \mathrm{KH}_{2} \mathrm{PO}_{4}, 4 \mathrm{mM} \mathrm{MgCl}_{2},{ }^{39}$ re-centrifuged at $700 \times g_{\text {av }}$ for $10 \mathrm{~min}$ at $4^{\circ} \mathrm{C}$ and dissolved in the same buffer.

To test for internucleosomal DNA cleavage, $10 \mu \mathrm{g}$ DNA isolated from variously treated hepatocytes was electrophoresed on $1.5 \%$ agarose gels and the DNA visualized by staining with ethidium bromide. ${ }^{5}$

\section{Metabolic labeling of cellular phosphoproteins, two-dimensional gel electrophoresis}

Suspension cultures of hepatocytes $\left(2 \times 10^{6} / \mathrm{ml}\right)$ were preincubated for $35 \mathrm{~min}$ in a low-phosphate $(0.1 \mathrm{mM})$ Krebs-Ringer bicarbonate buffer as described above, with $0.5 \mathrm{mCi} / \mathrm{ml}^{32} \mathrm{Pi}$. The cells were incubated with $\mathrm{MC}$ or the protein kinase inhibitor KT-5926, and the phosphorylated proteins visualized by autoradiography after separation by $2 \mathrm{D}$-gelelectrophoresis as described previously. ${ }^{11}$

\section{Scoring of cell budding, actin distribution, chromatin hypercondensation, cell and organelle volume changes by light microscopy}

Cells were removed form the cell suspension cultures at different time points after addition of apoptosis modulator and fixed in $1.5 \%$ glutaraldehyde. The presence of cell budding was evaluated using phase and differential interference contrast (DIC) microscopy.

For simultaneous visualization of actin and chromatin, the cells were fixed in $2 \%$ formaldehyde ( $\mathrm{pH} 7.4)$ with Hoechst $33342(5 \mu \mathrm{g} / \mathrm{ml})$, transferred to cover slides using a Cytospin (Shandon Inc., USA), permeabilized with Triton-X100 (0.05\%) for 20 min, washed with blocking buffer, and the actin stained with $0.5 \mu \mathrm{g} / \mathrm{ml}$ rhodamine-phalloidin. A Zeiss ApoTome ${ }^{\mathrm{TM}}$ grid projection system was used for optical sectioning.

For determination of cellular and nuclear shrinkage, cells were fixed in $1.5 \%$ formaldehyde and stained with Hoechst 33342 . Cells were mounted under coverslips and examined using a UV-equipped Zeiss Axiophot M200 inverted microscope with a digital camera. The relative cell and nuclear volume was determined by superimposing a transparent test system over the micrographs, and relate the total count of test points in the cytoplasm and nucleus to the counts in control cells. Results were plotted as size (\%) of the cytoplasm or nucleus of treated cells compared to their control size (100\%). At least 50 cells from each time point were measured in three independent experiments.

\section{Morphometry of transmission electron microscopy (TEM) ultramicrographs}

The cells were fixed for 15 min in $1.5 \%$ glutaraldehyde in Na-cacodylate buffer ( $\mathrm{pH} 7.4$ ) and kept on ice during the procedure. The cells were spun down, and washed in buffer before being post-fixed for $60 \mathrm{~min}$ in $1 \%$ osmium tetroxide $\left(\mathrm{OsO}_{4}\right)$. Dehydration was performed using graded alcohol solutions. After embedding the cells in Agar100 resin, ultra-thin sections were cut and stained in uranyl acetate and lead citrate. Sections were examined in a Philips EM 300/ll electron microscope. For determination of the nuclear volume and volume fraction, 15 electron micrographs were made randomly at final $\times 3200$ magnification from each section. The absolute nuclear volume was determined as described by Braendgaard and Gundersen. ${ }^{40}$ The number of nuclei per cell was next determined by fluorescent microscopy of hepatocytes stained with Hoechst 33342. The mean number of nuclei per cell was counted for 300 cells.

Based on the absolute average volume per nucleus and the average number of nuclei per cell, the absolute total nuclear volume per cell was determined. This value divided by the nuclear volume fraction (see below) yielded the absolute cell volume. The reason for determining the cell volume in this indirect way was that the nuclear shape was near globular even in strongly apoptotic cells, whereas the cell shape was distorted with numerous blebs, making the determination of absolute volume less reliable. ${ }^{40}$ Two presumptions were made prior to the determinations of the mean cell volumes. The mean number of nuclei within each hepatocyte was 1.4, as determined by quantification of Hoechst-stained cells (not shown). Each nucleus was of similar size, independent of being within a mono- or binuclear cell.

The volume fractions of nuclei, mitochondria, and glycogen were measured by superimposing a transparent multipurpose test system over the micrographs and relate the total count of test points over nuclei to the total count of cellular test points. For determination of the mean mitochondrial volume, 15 micrographs (magnification $\times 8000$ ) were made of isolated hepatocytes from each experiment.

\section{Determination of the CaMKII-dependent commitment time points for hepatocyte budding, chromatin hypercondensation, and loss of attachment and protein synthesis ability}

The time point when inhibition of CaMK by KT5926 or KN93 could no longer prevent irreversible cell damage by $\mathrm{MC}$ was determined for freshly 
isolated rat hepatocytes in suspension culture. Suspension cultures $\left(1.2 \times 10^{6} / \mathrm{ml}\right)$ of hepatocytes were treated with 0.5 or $2 \mu \mathrm{M} \mathrm{MC}$. After various incubation periods, aliquots were withdrawn and diluted 20- or 25fold in medium containing $5 \mathrm{mg} / \mathrm{ml} \mathrm{BSA}, 12.5 \mu \mathrm{g} / \mathrm{ml}$ pancreatic trypsin inhibitor and $30 \mu \mathrm{M}$ KN93 or $40 \mu \mathrm{M} \mathrm{KT5926,} \mathrm{and} \mathrm{scrutinized} \mathrm{later} \mathrm{for}$ apoptotic indices or washed and plated, as described in the legends to the relevant figures.

\section{Acknowledgements}

We are grateful to Gunnar Mellgren for participation in early studies leading to this work, and to Nina Lied Larsen, Erna Finsås, and Anne Nyhaug for excellent technical assistance. This work was supported by grants from The Norwegian Cancer Society, The Norwegian Research Council, The Novo Nordic Foundation, and a Functional Genomic (FUGE) grant to PROBE (Natl. Norw. Proteomics Unit).

\section{References}

1. Cohen PT (2002) Protein phosphatase 1 - targeted in many directions. J. Cell Sci. 115 (Part 2): 241-256

2. Sontag $E$ (2001) Protein phosphatase $2 A$ : the Trojan Horse of cellular signaling. Cell Signal. 13: 7-16

3. Sandal T, Aumo L, Hedin L, Gjertsen BT and Døskeland SO (2003) Irod/lan5: an inhibitor of gamma-radiation- and okadaic acid-induced apoptosis. Mol. Biol. Cell. 14: 3292-3304

4. Bøe R, Gjertsen BT, Vintermyr OK, Houge G, Lanotte M and Døskeland SO (1991) The protein phosphatase inhibitor okadaic acid induces morphological changes typical of apoptosis in mammalian cells. Exp. Cell Res. 195: 237-246

5. Gjertsen BT, Cressey LI, Ruchaud S, Houge G, Lanotte M and Døskeland SO (1994) Multiple apoptotic death types triggered through activation of separate pathways by CAMP and inhibitors of protein phosphatases in one (IPC leukemia) cell line. J. Cell Sci. 107: 3363-3377

6. Yatsunami J, Fujiki H, Suganuma M, Yoshizawa S, Eriksson JE, Olson MO and Goldman RD (1991) Vimentin is hyperphosphorylated in primary human fibroblasts treated with okadaic acid. Biochem. Biophys. Res. Commun. 177 $1165-1170$

7. Eriksson JE, Paatero GI, Meriluoto JA, Codd GA, Kass GE, Nicotera P and Orrenius $S$ (1989) Rapid microfilament reorganization induced in isolated rat hepatocytes by microcystin-LR, a cyclic peptide toxin. Exp. Cell Res. 185: 86-100

8. Toivola DM, Goldman RD, Garrod DR and Eriksson JE (1997) Protein phosphatases maintain the organization and structural interactions of hepatic keratin intermediate filaments. J. Cell Sci. 110: 23-33

9. Hooser SB, Beasley VR, Lovell RA, Carmichael WW and Haschek WM (1989) Toxicity of microcystin LR, a cyclic heptapeptide hepatotoxin from Microcystis aeruginosa, to rats and mice. Vet. Pathol. 26: 246-252

10. Fladmark KE, Brustugun OT, Hovland R, Boe R, Gjertsen BT, Zhivotovsky B and Døskeland SO (1999) Ultrarapid caspase-3 dependent apoptosis induction by serine/threonine phosphatase inhibitors. Cell Death Differ. 6: 1099-1108

11. Fladmark KE, Brustugun OT, Mellgren G, Krakstad C, Bøe R, Vintermyr OK Schulman $\mathrm{H}$ and Døskeland SO (2002) $\mathrm{Ca}^{2+} /$ calmodulin-dependent protein kinase II is required for microcystin-induced apoptosis. J. Biol. Chem. 277: 2804-2811

12. Schulman $\mathrm{H}$ and Hanson $\mathrm{PI}$ (1993) Multifunctional $\mathrm{Ca}^{2+} /$ calmodulin-dependent protein kinase. Neurochem. Res. 18: 65-77

13. Colbran RJ (2004) Targeting of calcium/calmodulin-dependent protein kinase II. Biochem. J. 378: 1-16

14. Wright SC, Schellenberger U, Ji L, Wang H and Larrick JW (1997) Calmodulindependent protein kinase II mediates signal transduction in apoptosis. FASEB J. 11: $843-849$
15. Ding WX, Shen HM and Ong CN (2000) Critical role of reactive oxygen species and mitochondrial permeability transition in microcystin-induced rapid apoptosis in rat hepatocytes. Hepatology 32: 547-555

16. Ding WX and Nam Ong CN (2003) Role of oxidative stress and mitochondrial changes in cyanobacteria-induced apoptosis and hepatotoxicity. FEMS Microbiol. Lett. 220: 1-7

17. Ding W-X, Shen H-M and Ong CN (2001) Pivotal role of mitochondrial $\mathrm{Ca}(2+)$ in microcystin-induced mitochondrial permeability transition in rat hepatocytes. Biochem. Biophys. Res. Commun. 285: 1155-1161

18. Liu X, Kim CN, Yang J, Jemmerson R and Wang X (1996) Induction of apoptotic program in cell-free extracts: requirement for dATP and cytochrome c. Cell 86: 147-157

19. Burkitt MJ, Milne L, Nicotera P and Orrenius S (1996) 1,10-Phenanthroline stimulates internucleosomal DNA fragmentation in isolated rat-liver nuclei by promoting the redox activity of endogenous copper ions. Biochem. J. 313: 163169

20. Chen YT, Zheng RL, Jia ZJ and Ju Y (1990) Flavonoids as superoxide scavengers and antioxidants. Free Radic. Biol. Med. 9: 19-21

21. Blankson H, Grotterod EM and Seglen PO (2000) Prevention of toxin-induced cytoskeletal disruption and apoptotic liver cell death by the grapefruit flavonoid, naringin. Cell Death Differ. 7: 739-746

22. Kerr JF (1971) Shrinkage necrosis: a distinct mode of cellular death. J. Pathol. 105: $13-20$

23. Wyllie AH, Morris RG, Smith AL and Dunlop D (1984) Chromatin cleavage in apoptosis: association with condensed chromatin morphology and dependence on macromolecular synthesis. J. Pathol. 142: 67-77

24. Bortner CD and Cidlowski JA (2003) Uncoupling cell shrinkage from apoptosis reveals that $\mathrm{Na}^{+}$influx is required for volume loss during programmed cell death. J. Biol. Chem. 278: 39176-39184

25. Dumont C, Durrbach A, Bidere N, Rouleau M, Kroemer G, Bernard G, Hirsch F, Charpentier B, Susin SA and Senik A (2000) Caspase-independent commitment phase to apoptosis in activated blood $\mathrm{T}$ lymphocytes: reversibility at low apoptotic insult. Blood 96: 1030-1038

26. Longthorne VL and Williams GT (1997) Caspase activity is required for commitment to Fas-mediated apoptosis. EMBO J. 16: 38053812

27. Samejima K, Tone S, Kottke TJ, Enari M, Sakahira H, Cooke CA, Durrieu F, Martins LM, Nagata S, Kaufmann SH and Earnshaw WC (1998) Transition from caspase-dependent to caspase-independent mechanisms at the onset of apoptotic execution. J. Cell Biol. 143: 225-239

28. McCarthy NJ, Whyte MK, Gilbert CS and Evan GI (1997) Inhibition of Ced-3/ICE-related proteases does not prevent cell death induced by oncogenes, DNA damage, or the Bcl-2 homologue Bak. J. Cell Biol. 136: 215-227

29. Sandal T, Ahlgren R, Lillehaug J and Døskeland SO (2001) Establishment of okadaic acid resistant cell clones using a cDNA expression library. Cell Death Differ. 8: 754-766

30. Moller MT, Samari HR, Fengsrud M, Stromhaug PE, Østvold AC and Seglen PO (2003) Okadaic acid-induced, naringin-sensitive phosphorylation of glycine $\mathrm{N}$-methyltransferase in isolated rat hepatocytes. Biochem. J. 373: 505-513

31. Mills JC, Stone NL, Erhardt J and Pittman RN (1998) Apoptotic membrane blebbing is regulated by myosin light chain phosphorylation. J. Cell Biol. 140: 627-636

32. Ikebe M and Reardon S (1990) Phosphorylation of smooth myosin light chain kinase by smooth muscle $\mathrm{Ca}^{2+} /$ calmodulin-dependent multifunctional protein kinase. J. Biol. Chem. 265: 8975-8978

33. Døskeland AP, Vintermyr OK, Flatmark T, Cotton RG and Døskeland SO (1992) Phenylalanine positively modulates the cAMP-dependent phosphorylation and negatively modulates the vasopressin-induced and okadaic-acid-induced phosphorylation of phenylalanine 4-monooxygenase in intact rat hepatocytes. Eur. J. Biochem. 206: 161-170

34. Hudmon $A$ and Schulman $H$ (2002) Structure-function of the multifunctional $\mathrm{Ca}^{2+} /$ calmodulin-dependent protein kinase II. Biochem. J. 364: 593-611

35. Strack S, Barban MA, Wadzinski BE and Colbran RJ (1997) Differential inactivation of postsynaptic density-associated and soluble $\mathrm{Ca}^{2+} /$ calmodulindependent protein kinase II by protein phosphatases 1 and 2 A. J. Neurochem. 68: $2119-2128$ 
36. Howe CJ, Lahair MM, McCubrey JA and Franklin RA (2004) Redox regulation of the calcium/calmodulin-dependent protein kinases. J. Biol. Chem. 279: 44573-44581

37. Vanden Berghe T, Denecker G, Brouckaert G, Vadimovisch Krysko D, D'Herde $\mathrm{K}$ and Vandenabeele $\mathrm{P}$ (2004) More than one way to die: methods to determine TNF-induced apoptosis and necrosis. Methods Mol. Med. 98: 101-126

38. Mellgren G, Vintermyr OK and Døskeland SO (1995) Okadaic acid, cAMP, and selected nutrients inhibit hepatocyte proliferation at different stages in G1: modulation of the cAMP effect by phosphatase inhibitors and nutrients. J. Cell Physiol. 163: 232-240

39. Jones DP, McConkey DJ, Nicotera P and Orrenius S (1989) Calcium-activated DNA fragmentation in rat liver nuclei. J. Biol. Chem. 264: 6398-6403

40. Braendgaard $\mathrm{H}$ and Gundersen $\mathrm{HJ}$ (1986) The impact of recent stereological advances on quantitative studies of the nervous system. J. Neurosci. Methods 18: $39-78$ 